\title{
Woyzeck and the birth of the human research subject. Genetic disposition and the nature-nurture debate through the looking-glass of fiction
}

\author{
Hub Zwarta \\ a Radboud University Nijmegen - Faculty of Science - Department of Philosophy (Chair) \\ Institute for Science, Innovation and Society (ISIS, Director of Education) \\ Centre for Society and the Life Sciences (CSG, Scientific Director)
}

\begin{abstract}
In various writings Michel Foucault has shown how, in the beginning of the $19^{\text {th }}$ century, in settings such as army barracks, psychiatric hospitals and penitentiary institutions, the modern human sciences were 〈born〉 as an ensemble of disciplines (medical biology, psychiatry, psychology, criminology, and the like). From the beginning, the nature-nurture debate has been one of its key disputes. Are human individuals malleable by environmental factors (such as psychiatric treatments or disciplinary regimes), or do they rather display inborn predispositions for delinquency and other forms of antisocial behaviour? In the current era of genetic testing, in behavioural genomics and neuroscience, this issue is as controversial and topical as ever. Büchner's unfinished drama Woyzeck (written in 1836) is a remarkable anticipation of this debate, staging the birth of the human individual as a research subject. It is the story of a destitute soldier who, according to his superiors, displays errant behaviour and is therefore recruited to serve as a research subject in an experiment. His army physician turns him into a 〈case〉, which can be meticulously monitored and studied so as to record the genesis of a crime. In this paper, Büchner's unsettling play is analysed in detail as one of the great anticipatory literary documents of the $19^{\text {th }}$ century, exploring the idea of predictive psychiatry and the quest for genetic predispositions: a primal scene as it were of the nature-nurture debate as it unfolds from predictive criminology up to behavioural genomics.
\end{abstract}

Key terms: Woyzeck - Georg Büchner - Michel Foucault - genetic predispositions - antisocial behaviour - research involving human subjects - science and literature

\section{Prelude: chromosome dialogues}

1962 was a remarkable year, for various reasons. The Beatles recorded their first single (Love Me Do) at Abbey Road Studios in London, the Rolling Stones made their debut at the Marquee Club (also in London), and James Watson, Francis Crick and Maurice Wilkins were awarded the Nobel Prize for their role in the discovery of the double helix (in 1953).

But 1962 was also the year of the premiere of Edward Albee's classic play Who's afraid of Virginia Woolf, which opened on Broadway on October 13 and addressed a whole range of topical issues, such as childlessness, alcohol abuse and the dreariness of academic campus life. Moreover, it staged an interesting discussion on the new biology that was emerging in laboratories at that time, notably involving chromosome research. Here is an excerpt from the dialogue between Nick (a young biologist) and George (an elderly historian), representing two generations, but also two cultures - the life sciences and the humanities:

George: Martha says you're in the Math Department, or something.

Nick: No ... I'm not ... I'm a biologist. I'm in the Biology Department.

George: (After a pause) Oh. (Then, as if remembering something) Oh! You're the one! You're the one's going to make all that trouble ... making everyone the same, rearranging the chromozones, or whatever it is. Isn't that right?

Nick: (With that small smile) Not exactly: chromosomes.

George: ... I'm really very mistrustful. Do you believe that people learn nothing from history? ... Biology, hunh? I read somewhere that science fiction is really not fiction at all ... that you people are rearranging my genes, so that everyone will be like everyone else. Now, I won't have that! ... There will be a certain ... loss of liberty, I imagine, as a result of this experiment ... but diversity will no longer be the goal. Culture and races will eventually vanish ... the ants will take over the world.

Nick: You ... You don't know much about science, do you?

The synchronicity between Albee's play and the 1962 Nobel Prize is no coincidence. Authors such as Albee are the seismographs of their epoch, sensing and registering important developments and shifts. They are the therapists of their time, whose job it is to assess the moods, symptoms and mental condition of their own era. Apparently, Albee as a gifted, sensitive author had spotted that, in the 1960s, chromosomes were in the air, although public culture (represented by George) still had to gain some fluency and articulacy when it 
came to addressing the wider issues involved in DNA discoveries.

Yet, George's 〈free associations〉 did manage to capture the general attitude of the time. Although the official rationale of molecular biology is no doubt to discover new pathways for improving human health, this research practice may have other («collateral〉) implications as well. It may eventually allow us to modify and enhance our genetic Self, to «rearrange our genes», as George phrases it - no doubt in order to forego problems such as involuntary childlessness or alcohol abuse, whose detrimental consequences are so vividly fleshed out in Albee's play. This may even be seen as the new biology's hidden agenda, either consciously or unconsciously: to strengthen our sway over human existence on a molecular level. And this is of course what George is pointing at. Representing the general attitude of the 1960s, he voices an unequivocal zero tolerance attitude towards such genetic deterministic ideas, implicitly referring to experiences with Nazism during World War II («Do you believe that people learn nothing from history?») to strengthen his point.

Albee's play is far from exceptional in this respect. There is a long list of novels, plays and movies that aim to address attitudes and views (either latent or prevailing) concerning the possible consequences of genetics for human existence. Perhaps the first literary document within this genre, the embryonic version as it were of what has by now grown into a spate of textual materials, was Georg Büchner's Woyzeck, written in 1836 , long before the actual onset of genetics research as such, but addressing issues that are still highly relevant today, notably the issue of a supposedly inborn predisposition for deviant behaviour and delinquency. Unfinished, it was all but forgotten and remained unperformed until 1913. Like Mendel's famous paper, Büchner's drama had to be unearthed. And yet, it can be regarded as a kind of literary anticipation of the «Century of the gene» [1] and of some of the key moral quandaries involved in it.

\section{Woyzeck and the birth of the human sciences}

One of the grand intellectual disputes of the «entury of the gene> has been the Nature - Nurture debate. As Nelkin and Lindee [2] convincingly point out, this debate followed a series of pendulum swings from «nature〉 (which, due to genetics, increasingly came to be equated with our genetic predisposition) towards 〈nurture〉 (i.e. the social environment) and back again. From 1900 until 1935, due to ideas and insights coming from genetics, combined with the impacts of evolution theory and social Darwinism, the nature-paradigm held sway. Indeed, the first decades of the $20^{\text {th }}$ century can be regarded as the heydays of the eugenics movement, notably in the United States. After 1935, how- ever, a rapid decline set in, partly due to scientific developments (the growing criticism concerning the supposedly hereditary nature of complex traits such as aptitude for alcoholism or delinquency) but also because of the rise of Nazism in Germany, with its outspoken eugenic agenda. After World War II, the emphasis on «nature had been sufficiently discredited and 〈nurture〉 became the dominant paradigm. Notably in explaining and addressing anti-social behaviour, poverty or delinquency, the focus now was on environmental and social factors. During the 1980s, this began to change again. The pendulum once again swung backwards - a development that more or less coincided with the decline of communism and the collapse of the Berlin Wall in 1989. As Nelkin and Lindee phrase it: «By 1992, the consensus that had dominated public policy since the 1950 s - that «nurture» was more important than «nature - was changing» [3]. Society began to accept biological differences. Inherited predispositions returned on the agenda as an issue of concern for society and science.

A similar pattern had already emerged during the $19^{\text {th }}$ century. In various studies, Michel Foucault describes how the modern human sciences were 〈born〉 in the beginning of the $19^{\text {th }}$ century, as an ensemble of disciplines (medical biology, psychiatry, psychology, criminology, and the like) developed to further knowledge about ourselves as living social beings through empirical research and anthropometric measurements. Given the fact that in the wake of the Napoleon wars general conscription had been implemented in many Western countries, soldiers (but also prisoners, psychiatric patients and the like) became research subjects of choice for providing the necessary anthropometric data. In the $19^{\text {th }}$ century, Foucault argues, large-scale institutions especially designed for the purpose of disciplining the masses were established throughout Europe. Thousands of human bodies were accumulated in army barracks, factories and prisons [4] where they were to be transformed into reliable army units and / or a productive work force in support of the industrial revolution. These new spaces became <laboratories of power> [5], where individuals functioned as research subjects, exposed to the gaze of surveillance, to examinations and measurements, to training programs and dietary regimes: technologies developed for the purpose of producing useful, accountable, employable human beings [6]. At the same time, there emerged a science of the individual, regarded as a case [7]. Thus, these new 〈panoptic spaces became the laboratories of the new human sciences whose focus shifted to individual-as-files, accessible for examination and scrutinised meticulously as experimental protocols [8]. In this manner, a new type of knowledge about ourselves (medical and otherwise) emerged. And in this context arose the dispute concerning the malleability of human bodies - and of human nature in general. Although genetic testing strictly speaking belongs to 
the $20^{\text {th }}$ century, the $19^{\text {th }}$ century already witnessed the emergence of what may be regarded as a preparatory discourse, namely the debate (within the human sciences in general, but within criminology in particular) over inherited dispositions of individuals.

One of the key players in this $19^{\text {th }}$ century version of the nature-nurture debate was Cesare Lombroso (18351909) who was very outspoken in his claim that criminality was an innate condition and that a «born delinquent> could be identified on the basis of certain physical, physiognomic and behavioural traits (which he called stigmata). In fact, he regarded the naturally born delinquent as a retarded, atavistic subspecies of Homo sapiens. In more recent disputes, the Lombroso legacy continues to play a role. It has been vehemently rejected and criticised by some [9], but has been embraced and rehabilitated (partly at least) by others. The pendulum pattern within scientific discourse is mirrored in literary documents as well. In 1912, for instance, during the heydays of the eugenics movement, G. Frank Lydston, who also authored a number of scholarly eugenic writings, published a play entitled The blood of the fathers about a socially aware young doctor (with a strong interest in the theories of Lombroso) who at a certain point realises that he has fallen in love with the «wrong) girl, namely with a woman who is hopelessly tainted by her inherited aptitude for criminal behaviour. Subsequently, in 1962, as we have seen, the pendulum of public consensus had firmly shifted towards the nurture-side. Indeed, Albee (using George as his mouthpiece) voices a firm rejection of what later came to be known as the <geneticisation> of human beings. Yet, in 1992, the opposite view gained ground again. In a suspense novel entitled A Philosophical Investigation authored by Philip Kerr, for instance, the turn towards the nature-paradigm is clearly reflected. As Lindee and Nelkin phrase it, Kerr «describes a twenty-first century society ravaged by an epidemic of violent crime ... All males carry identification cards with their DNA profiles and are expected to participate in the 〈Lombroso Program〉 that will screen them for innate predispositions. Lombroso (Localization of Medullar Brain Resonations Obliging Social Orthopraxy) Clinics employ a scanning machine resembling that used in Positron Emission Tomography to identify men ... likely to become criminals» [10]. The idea is to track down offenders before they are actually able to offend.

In this paper, I will return to the very beginning, by rereading the primal source: a literary document that anticipates this whole debate in a remarkably vivid and concise manner. Woyzeck, the first literary text in which scientific explorations concerning the possible presence of a criminal predisposition in human individuals are explicitly discussed, still proves remarkably relevant today. Building on my analysis of Woyzeck I will argue that, when it comes to addressing the philosophical and bioethical dimensions of emerging life sci- ences, genres of the imagination (novel, plays, movies and the like) can play a pivotal role. They help us to probe and explore the meaning of complex techno-scientific developments for human existence. This also applies to the field of genetic testing as it evolves today. As a literary classic, Woyzeck contains some important moral messages, even for current genetics practices, thus providing valuable source material - for example for ethics courses for science students. The play was written in 1836 by Georg Büchner (a young German physician and revolutionary), shortly before his untimely death, ${ }^{1}$ and stands out as a critical anticipation of $19^{\text {th }}$ and $20^{\text {th }}$ century thoughts on the issue of inborn delinquent aptitudes.

\section{Woyzeck - a close rereading}

The tragedy Woyzeck ${ }^{2}$ is held in high regard, by contemporary audiences, but also by stage directors, literature scholars and critics alike, not only because of its bleak atmosphere, but also because of its lowbrow language, its fast tempo and its sequence of very short scenes, of concise dramatic vignettes, which makes it astonishingly similar to a modern movie script, much more than any other instance of $19^{\text {th }}$ century drama. Moreover, Büchner's unfinished tragedy stages working class people rather than bourgeois or aristocratic characters, at a time when this was still highly unusual. ${ }^{3}$ Thus, Woyzeck is often regarded as a proletarian tragedy, because it deals with the dramatic life story of a poor, desolate soldier - ruthlessly exploited by his superiors as a menial servant - and his enchanting low-class mistress Marie.

For me, however, the exceptional originality of Büchner's drama first of all resides in the fact that it stages (for the very first time) a completely new type of character, a new type of role played by human beings, both on stage as well as off stage, namely that of a research subject. Of course, a whole train of patients had been put on stage already, in the plays of Molière and others as well as in medieval morality plays - and these patients had been exposed to all kinds of questionable treatments. Furthermore, there had already been plays about researchers conducting experiments - such as

1 Woyzeck was written in 1836 and left incomplete at Büchner's death in 1837. It was performed for the first time in 1913 in $\mathrm{Mu}-$ nich, in the midst of the eugenics era.

2 There are countless editions of Woyzeck, both in German and in English translation, and - as the play written by Büchner was actually an unfinished draft - there are many notable differences between these various versions. Therefore, for practical purposes, I will use and refer to the digital Gutenberg-version of the play (the German version), easily accessible to all readers [11].

3 Aristotle [12] had stipulated that the vicissitudes of individuals of high station should be dealt with in tragedies, while representatives from the lower classes should appear in comedies. As Foucault points out, from now on, criminals, hysterics and psychiatric patients rather than aristocrats will become the heroes of 19th century belles-lettres: «à la place de Lancelot, le président Schreber» [13]. 
Diderot's scientific comedy Dream of d'Alembert. Still, Woyzeck is without precedent because it casts for the very first time a human individual as a research subject participating in a trial explicitly designed to demonstrate a theoretical point of view, to systematically examine a hypothesis. And indeed, in accordance with the experimenter's theory, and as a confirmation of his hypothesis, Woyzeck starts to develop symptoms of paranoid schizophrenia as the play unfolds. Thus, the play literally reflects and adheres to an experimental design involving a human subject $(\mathrm{N}=1)$. It stages an experiment, set up with no other purpose than to test the very idea of a criminal predisposition as such.

In doing so, Woyzeck seems to anticipate important concepts and ideas in an astonishingly straightforward manner. To begin with, its author was well-versed in comparative anatomy and had written a thesis on the cranial nerves of the catfish, which led to his appointment as lecturer in comparative anatomy at Zurich (where he lived as a political refugee because of his revolutionary commitments). No doubt, these scholarly activities must have triggered preliminary reflections on the genesis of psychic aberrations and crime. Indeed, one could even argue that his anatomical research (on fish brains) and his theatrical analysis (involving a mentally disturbed research subject) mirror one another, so that Woyzeck becomes a kind of literary forensic or psychological-judicial 〈autopsy〉 [14]. Franz Woyzeck is presented as an uncanny individual who, at least in the eyes of his superiors, displays awkward behaviours. From the very beginning, he is cast as a potential suspect, a suspicious personage, well before he actually commits his passionate, desperate crime. Notably, his restlessness, his restless gait, his inability to stay calm, his 〈hyperactivity〉 (as we would probably call it nowadays) are seen by his superiors as highly disconcerting traits. Especially the Captain, who employs Woyzeck as his private barber, is upset by it. ${ }^{4}$ Indeed, as the Captain phrases it, normal individuals, with a clear conscience, will do things at a much slower pace, will display a much calmer gait. ${ }^{5}$ Woyzeck, in other words, tends to get on other people's nerves. ${ }^{6}$

The Physician, however, primarily sees him as an interesting case study. ${ }^{7}$ He uses Woyzeck as a research subject in a ground-breaking experimental trial. Apparently, he aims to bring Woyzeck's latent disposition to the fore, by exposing him to a series of carefully

4 HAUPTMANN: Langsam, Woyzeck, langsam; eins nach dem andern! Er macht mir ganz schwindlig ... Er macht mich ganz konfus ... Du siehst immer so verhetzt aus. - Geh jetzt, und renn nicht so; langsam, hübsch langsam die Straße hinunter!

5 HAUPTMANN: Woyzeck, Er sieht immer so verhetzt aus! Ein guter Mensch tut das nicht, ein guter Mensch, der sein gutes Gewissen hat ... Woyzeck, Er hat keine Tugend! Er ist kein tugendhafter Mensch!

6 HAUPTMANN: Er macht mich ganz konfus ... He, Woyzeck, was hetzt Er sich so an uns vorbei. Bleib er doch, Woyzeck! Er läuft ja wie ein offnes Rasiermesser durch die Welt, man schneidt sich an Ihm.

7 DOKTOR: Er ist ein interessanter Kasus. Subjekt Woyzeck ... selected conditions - first of all by subjecting him to a strict diet consisting only of peas. ${ }^{8}$ Woyzeck is quite literally a play on nature versus nurture, where «nature〉 stands for inherited disposition and «nurture〉 stands for food intake. Woyzeck is requested to eat nothing but peas and to report at the Physician's office every 24 hours, allowing the latter to collect samples of Woyzeck's urine for analysis. And for this, Woyzeck, the impoverished soldier, is paid a small sum. During their first interview, the Physician blames Woyzeck because he noticed him urinating on the public road «like a dog» - thereby putting the whole experiment at risk. Woyzeck defends himself by arguing that it simply was his «nature that forced him to release himself, but the Physician lectures him, arguing that human beings have the ability to restrain themselves, ${ }^{9}$ that is: to live up to their duties. In Woyzeck's case, this means: living up to his duties as a research subject, stipulated in a contract, apparently a kind of informed consent document, bearing Woyzeck's signature. ${ }^{10}$ Notwithstanding the obvious parody at work in these cynical and burlesque short scenes, there is a rather profound element of realism and truth in them as well. Woyzeck is not <a tragic story of human experiment without informed consent>, as Wolf has claimed [16]. Quite the contrary: the play meticulously stages a crucial moment in the history of the human sciences, namely the birth of the human research subject, in possession of a contract stipulating informed consent (as an indispensable laboratory item).

Woyzeck's physical condition is meticulously monitored. ${ }^{11}$ At a certain point, he is taken to an amphitheatre, where he is presented to a group of students as a human specimen who, having eaten nothing but peas for almost three months, may now be surveyed by them. They are requested to feel his temple and his pulse and to inspect his eyes. The amphitheatre (where 〈cases〉 of special interest are presented to academic audiences, exposed to the gaze of scholarly voyeurism) constitutes a theatre within a theatre, a play within a play. We (readers or audiences) form a second row of students, witnessing how the drama (the staged experiment) unfolds, while Woyzeck's mood and condition gradually deteriorates. Scene by scene, his skull is lifted as it were, to reveal and acutely study the hidden mechanisms of his tormented nervous system. Thus, a touch of cranial autopsy (his scholarly research field)

8 Thus, Woyzeck, like Mendel's 1886 paper, is one of the famous pea stories of the $19^{\text {th }}$ century. Andersen's well-known fairy-tale, The princess and the pea (published in 1835), dates from the same period as Woyzeck and likewise stages an experiment, designed to establish whether the 〈research subject> in question really is a born princess, endowed with a remarkably high level of sensitivity [15].

9 DOKTOR: Die Natur! Hab' ich nicht nachgewiesen, daß der Musculus constrictor vesicae dem Willen unterworfen ist? Die Natur! Woyzeck, der Mensch ist frei, in dem Menschen verklärt sich die Individualität zur Freiheit. - Den Harn nicht halten können!

10 DOKTOR: Ich hab's schriftlich, den Akkord in der Hand!

11 DOKTOR: Den Puls, Woyzeck, den Puls! - Klein, hart, hüpfend, unregelmäßig ... Gesichtsmuskeln starr, gespannt, zuweilen hüpfend. Haltung aufgeregt, gespannt ... 
enters Büchner's literary work as well. ${ }^{12}$ For the Physician, Woyzeck represents an ideal research subject, someone who depends on him for his income, but most of all as someone who - so the Physician hopes at least - will make him famous. ${ }^{13}$ In the beginning of the play, poor Woyzeck already begins to develop symptoms of what the Physician refers to «aberratio mentalis partialis, zweite Spezies [partial mental aberration, second category]», although current psychiatric vernacular would no doubt regard it as an instance of paranoid schizophrenia. Woyzeck begins to see strange things and to hear strange, unsettling voices. ${ }^{14} \mathrm{He}$ is concerned that a conspiracy (by an underground movement of freemasons) is unfolding.

One of the scenes of the play stages a discussion among drunkards on the meaning of life. Why do human beings exist? Or (in proto-existentialist German) «Warum ist der Mensch?» From the point of view of the Physician, Woyzeck's sole purpose in life is his being a research subject. Apparently, according to his superiors, Woyzeck's life (as a soldier, a menial servant, a research subject) only has instrumental value. He serves the researcher who may thus further serve the human sciences (for the benefit of future humans).

After weeks of eating nothing but peas, Woyzeck finds himself facing a crucial test, a highly challenging situation. He is confronted with a tall and muscular Drum Major who soon becomes his rival as the latter sets out to seduce (and in the end, to violate) Woyzeck's alluring mistress Marie. During a tavern brawl, Woyzeck finds himself physically harassed by the brawny Drum Major - the embodiment of 〈phallocracy〉, eclipsing poor, powerless Woyzeck with his aura of drilled virility -, and in the end, he takes revenge on Marie for her unfaithfulness by stabbing her to death in a dreary moonlit night besides a fish pond. After this acting-out against Marie, in compliance with his physician's wish to commit an aberration, Woyzeck flees in despair, but returns to the crime scene once again, urged by a repetitive impulse, where he discovers Marie's pale body, her beautiful throat adorned by a necklace of red coral. For a brief moment, his cruel transgression seems to adhere to the concept of murder as a form of art [18]. He utters his final sentences to her and throws the knife into the water, but his hands remain covered with his victim's blood. His blood-stained hands become yet another symptom with which he (the predestined criminal) betrays himself.

12 In a letter to the author, his friend Karl Gutzkow points out that an element of autopsy pervades everything Büchner writes («Ihre Autopsie, die aus allem spricht, was Sie schreiben», 10 June 1836) [17]

13 DOKTOR: Es gibt eine Revolution in der Wissenschaft, ich sprenge sie in die Luft. Harnstoff 0,10 , salzsaures Ammonium, Hyperoxydul ...

14 WOYZECK: [...] eine fürchterliche Stimme [hat] zu mir geredt! ... Ich kann nit schlafen! Wenn ich die Aug zumach', dreht sich's immer, und ich hör' die Geigen, immer zu, immer zu. Und dann spricht's aus der Wand. Hörst du nix?
Büchner's play was based on real-life events, namely the famous case of Johan Christian Woyzeck who was beheaded in Leipzig in 1824 for murdering his mistress in a fit of jealous rage. At the time, this case made legal history because the accused had been subjected to lengthy medical examinations in order to establish whether his sentence should be reduced due to diminished responsibility. Büchner thoroughly studied this case and used several important details in his play. A famous lithography by Christian Geißler features Woyzeck as he is about to ascend the platform where he will be executed,,$^{15}$ surrounded by a mass audience, as if he is an actor in a play - as if Büchner's play is a repeat: a reworking of the original outdoor drama, staged in 1824 .

\section{Woyzeck and the birth of modern criminology}

The play can be regarded as an uncanny anticipation of $19^{\text {th }}$ century theories concerning human disposition, notably the ideas of Cesare Lombroso who, long before the onset of genetics and genetic testing, in a book entitled L'uomo delinquente (published in 1876) [20], had claimed that the violent disposition of «born criminals» can be established on the basis of certain physical, physiognomic and behavioural characteristics, which he called stigmata - in other words, by having a close look at their faces. Like the Physician in Büchner's play, Lombroso had been an army physician for a number of years. In this capacity, he had carried out anthropometric measurements on soldiers entrusted to his care. Subsequently, he worked in mental hospitals until in 1874 he was appointed lecturer in legal medicine and public hygiene at the University of Turin, where he later became professor of psychiatry and criminal anthropology.

Lombroso's basic idea was that born criminals (about $40 \%$ of the convict population, according to his estimates) have a strong, innate predisposition for what we nowadays would call antisocial behaviour. This type of criminal, Lombroso believed, represented a human subspecies that had failed to evolve sufficiently towards the more prevalent and advanced Homo sapiens type. These individuals constituted a kind of missing link between modern humans and more primitive anthropoid forms. He called this evolutionarily retarded subspecies Homo delinquens. These individuals lived among civilised humans, but actually they represented a more savage past, an era when criminal behaviour was normal and even prerequisite for survival. In short, Lombroso basically argued that criminals represented instances of atavism. They embodied the return of the repressed: of that which is primitive and animal-

15 I.C. Woyzeck geht seinem Tode als reuevoller Christ entgegen [19]. 
istic in human beings, notably males. The born criminal is a primitive specimen of humankind that somehow failed to become extinct and is still living in our midst. In these unfortunate individuals, a distant past, a lost world so to speak, has come to life again. Yet, with the help of modern science - criminal anthropology to be exact - we may identify them on the basis of anatomy and physiognomy. Their ears, for instance, are pointed; their brushy eyebrows meet over their aquiline noses, and they love street language, strong liquor and tattoos. Restlessness and impulsivity are also mentioned by Lombroso as typical stigmata of innate delinquency. ${ }^{16}$

Thus, seen from the perspective of the $19^{\text {th }}$ century human sciences, the apparently bizarre experiment to which Franz Woyzeck is being subjected suddenly makes sense. From the very outset, Woyzeck the research subject displays certain symptoms that (according to a Lombroso-like expert) seem to point to a delinquent «nature〉. With the help of «nurture〉 (diet), the subject's predisposition (his «nature ) is brought to the surface. In other words, by collecting anthropometric data (pulse measurements, urine samples and the like), the Physician closely monitors the genesis of a criminal act.

As Gould [22] points out, traces of Lombroso's ideas can be found in various literary documents of the $19^{\text {th }}$ century, ranging from Tolstoy's novel Resurrection up to Bram Stoker's classic Dracula. Indeed, Count Dracula, as depicted by Stoker, has several physiognomic features which Lombroso would consider highly suspect. ${ }^{17}$ Yet, the interesting thing about Woyzeck is that it was written well before, not after L'uomo delinquente. In fact, it was written shortly after Lombroso's birth (in 1835). Like Frankenstein (as an anticipation of transplantation medicine and tissue engineering) and Dracula (anticipating issues that would later be addressed in the context of blood transfusion, virology and psychotherapy), Woyzeck is one of the great anticipatory documents of modern literature, in which important scientific developments are forecasted and prospectively explored rather than interpreted in retrospect.

Although Lombroso's work has been discarded as unscientific by later generations of researchers, some aspects of his views nonetheless tend to resurge every now and then. The idea as such that some individuals may be born into this world with a strong inherent disposition for antisocial behaviour certainly seems to experience a revival in the present era of behavioural genomics. When for instance American scientists dis-

16 Physiological symptoms of inborn criminality can also be detected in urine: «In born criminals there is a diminished excretion of nitrogen, whereas that of chlorides is normal. The elimination of phosphoric acid is increased, especially when compared with the nitrogen excreted» [21].

17 «The count is a criminal and of criminal type ... Lombroso would so classify him, and quâ criminal he is of imperfectly formed mind» [23]. covered the XYY or «super-male〉 syndrome, studies initially seemed to suggest a correlation between this condition and violent behaviour. This was picked up in the 1992 Hollywood film Alien III, featuring a prison planet inhabited by XYY males who - as carriers of a criminal predisposition - were believed to be genetically prone to kill and incapable of rehabilitation. Moreover, Francis Fukuyama argued that, even if direct causal relationships between DNA and delinquency seem unlikely, the sheer accumulation of knowledge about genes and behaviour is bound to have significant societal consequences in the longer run [24]. In this context, he points to Lombroso, whose convictions concerning inborn aptitude for delinquency seem to be experiencing a rebirth. Human aggression is hard-wired, in some individuals more than in others, and genes are certainly involved. Human beings are by nature violent rather than peaceful, and the genetic basis for our innate violence may in the near future be uncovered in more detail [25].

Indeed, antisocial behaviour, as it is now called, is an important target for behavioural genomics. This notably applies to the emerging field of neuro-prediction: i.e. the identification of predictive factors for antisocial behaviour in high-risk individuals [26], focussing on specific neurocognitive biomarkers. According to Cheema and Virk [27], for instance, current studies suggest a genetic link between the Attention Deficit Hyperactivity Disorder (ADHD) in children and the risk of developing delinquency later in life. For them, this raises the question whether we are «reinventing Lombroso».

\section{Conclusion: Woyzeck's ımessages for current generations}

When it comes to determining the play's moral messages for today, some disclaimers must be mentioned. First of all, there is a substantial epistemological distance between (on the one hand) the views of Cesare Lombroso - shared by Woyzeck's Physician to some extent - and (on the other hand) the much more precise, nuanced and sophisticated views conveyed by contemporary behavioural genomics. Also, we must acknowledge the significant progress made on the ethical level, notably in terms of implementing informed consent procedures on the basis of the autonomy principle [28]. And yet, this being said, Woyzeck may still function as a mirror for the present. I do not mean to suggest that current research teams are as cynical and ruthless as Büchner's Physician, nor would I argue that Woyzeck proves that there is something fundamentally wrong per se with trying to discern a causal relationship between genetic disposition and delinquent behaviour. Rather, I see Woyzeck as a moral exercise, a lucid first effort to come to terms with newly emerging forms of biomedical knowledge, cul- 
minating in the genomics version of the human sciences of today.

As we find ourselves in the second decade of the $21^{\text {st }}$ century, the pendulum has swung once more. The genetic determinism that seemed to prevail in the 1990s, has given way to a more nuanced, interactionist view. Seen from our perspective, Woyzeck's crime must have resulted from a combination of his (to some extent schizoid) predisposition and the <external circumstances> to which he was exposed (notably: ruthless exploitation by irresponsible superiors, including his physician). Being a brilliant play, Woyzeck sensitises us to some of the key issues and dilemmas entailed in genetic testing. Although it does not provide clear recommendations as to how genetic testing in behavioural genomics should be implemented (such recommendations should not be expected from literary documents at all) a rereading of Woyzeck may function as a preparatory moral exercise, notably for students who are bound to become involved in molecular biology and behavioural genomics themselves.

\section{Post-script: a quick comparison between Georg Büchner's Woyzeck and Michael Crichton's Next}

Shortly before his death, Michael Crichton - author of Jurassic Park, the most famous genomics novel so far, which predicted that genomics would enable us to revivify extinct species from bygone epochs - published a novel entitled Next [29]. The title refers to Next Generation Sequencing, the new high through-put sequencing technologies that will not only make the personalised genomics era possible, but will probably also boost research in areas such as behavioural genomics. In this novel, Crichton explores what will happen when individuals begin to think about themselves in terms of their genetic predispositions, in terms of the genes that are detected on their genomes, such as the thrill-seeking gene, the sociability gene, the infidelity gene, etc. The novel functions as a literary laboratory where various scenarios are fleshed out, some of which involve genetic predispositions, criminal offences and lawsuits. Thus, Crichton's novel, staging a long series of very short scenes, can be regarded as a contemporary counterpart to Büchner's play.

One of the characters in the novel is accused of having sexually abused an under-aged girl, with whom he had spent the night. As his own line of defence (namely that it was a case of mutual desire) seems without much prospects, his lawyer suggests a «genetic defence» [30]. He proposes to argue in court that the defendant acted under the influence of the «novelty gene» (D4DR), a piece of DNA-code that allegedly predisposes individuals to take risks and engage in thrill-seeking behaviours. Thus, they begin to delve into the suspect's life history, to find support for their claim. Also in his daily life, he begins to indulge in risky behaviour more intensely, so that his affliction may even become more apparent. In the end, he even commits a murder although in this case the victim is a famous geneticist. In other words, like Woyzeck, Crichton's novel stages the genesis of a criminal act.

Woyzeck and Next mirror one another. Yet, while Woyzeck is a dreary tragedy, involving a destitute menial worker apparently deprived of any prospects for the future, Next reads like a soap-like comedy, featuring light-hearted individuals who spend their sunny lives in comfort and ease. In Next, the big issues (of genetic disposition and personal responsibility) have become miniaturised and trivialised. In other words, what according to Marx (following Hegel) applies to world-history as such, applies to literary characters and their vicissitudes as well: they make their appearance twice, the first time as tragedy, the second time as farce. Next may stand as Woyzeck's comic double. Together, they are the A and the $\Omega$ of two centuries of deliberation over «nature〉 versus «nurture〉.

\section{Zusammenfassung}

In verschiedenen Beiträgen hat Michel Foucault gezeigt, wie die Humanwissenschaften zu Beginn des 19. Jahrhunderts in Milieus wie Militärkasernen, Psychiatrien und Strafanstalten entstanden sind. Seit den Anfängen dieser Wissenschaften war die «naturenurture >-Debatte eine der zentralen Streitfragen. Sind menschliche Individuen durch Umwelteinflüsse (wie psychiatrische Behandlungen oder disziplinarische Regime) formbar oder zeigen sie angeborene Veranlagungen zur Delinquenz und zu anderen Formen antisozialen Verhaltens? In der gegenwärtigen Ära genetischer Tests, der Verhaltensgenetik und der Neurowissenschaft ist diese Frage aktueller und kontroverser denn je. Büchners unvollendetes Drama Woyzeck (geschrieben im Jahr 1836) nimmt diese Debatte auf bemerkenswerte Weise vorweg, indem es die Geburt des menschlichen Individuums als Forschungsgegenstand inszeniert. Es ist die Geschichte eines mittellosen Soldaten, der seinen Vorgesetzten zufolge irrendes Verhalten zeigt und deshalb als Forschungsobjekt für ein Experiment rekrutiert wird. Der Militärarzt macht aus ihm einen 〈Fall〉, der sorgfältig überwacht und studiert werden kann, und dokumentiert so die Entstehungsgeschichte eines Verbrechens. Dieser Artikel analysiert im Detail Büchners beunruhigendes Drama als eines der grossen vorgreifenden literarischen Dokumente des 19. Jahrhunderts, welches die Idee der prädiktiven Psychiatrie und die Suche nach genetischen Veranlagungen erkundet: gewissermassen eine Urszene der «nature-nurture〉-Debatte, die sich von der prädiktiven Kriminologie bis hin zur Verhaltensgenetik entfaltet. 


\section{Résumé}

Michel Foucault a montré dans plusieurs écrits comment les sciences humaines modernes sont «nées〉 comme ensemble de disciplines (biologie médicale, psychiatrie, psychologie, criminologie et d'autres) au début du $19^{\text {e }}$ siècle, dans des contextes comme des baraquements militaires, des hôpitaux psychiatriques et des institutions pénitentiaires. Dès le début, le débat sur l'inné et l'acquis a été un de leurs enjeux cruciaux. Les individus humains sont-ils malléables par des facteurs environnementaux (comme les traitements psychiatriques ou les régimes disciplinaires), ou présentent-ils plutôt des prédispositions innées pour la délinquance et d'autres formes de comportements antisociaux ? Dans l'ère actuelle des tests génétiques, de la génomique comportementale et des neurosciences, cet enjeu demeure tout aussi actuel et tout aussi controversé. Woyzeck, la pièce de théatre inachevée de Büchner (écrite en 1836) est une remarquable anticipation de ce débat, mettant en scène la naissance de l'individu humain comme sujet de recherche. C'est l'histoire d'un soldat indigent qui, selon ses supérieurs, fait preuve de comportements anormaux et se retrouve donc recruté pour servir de sujet de recherche dans une expérimentation. Ses médecins militaires le transforment en un 〈cas〉, pouvant être méticuleusement suivi et étudié pour documenter la genèse d'un crime. Dans cet article, cette pièce dérangeante de Büchner est analysée en détail comme un des grands documents de littérature anticipatoire du $19^{\mathrm{e}}$ siècle, explorant l'idée de la psychiatrie prédictive et la recherche de prédispositions génétiques : une scène primale, en quelque sorte, du débat inné vs acquis qui se développe de la criminologie prédictive à la génomique comportementale.

\section{Correspondence}

Prof. Dr. Hub Zwart

Radboud University Nijmegen

Department of Philosophy

P.O. Box $90106500 \mathrm{GL}$ the Netherlands

E-Mail: h.zwart[at]science.ru.nl

Manuscript submitted: 19.3.2013

Revisions submitted: 23.6.2013

Accepted: 25.6.2013

\section{References}

1. Fox Keller, E. The Century of the Gene. Cambridge Mass.: Harvard University Press, 2000.

2. Nelkin D., Lindee S. The DNA mystique: the gene as a cultural icon ( $2^{\text {nd }}$. Ed.). Ann Arbor: University of Michigan Press, 1995/2004.

3. Idem, p. 106

4. Foucault M. Surveiller et punir. Naissance de la prison. Paris: Gallimard, 1975, p. 222.

5. Idem, p. 206

6. Idem, p. 212.

7. Foucault M. Naissance de la clinique. Une archéologie du regard médical. Paris: Presses Universitaires de France, 1963, p. x).

8. Idem, p. xi.

9. For instance Gould S.J. The mismeasure of man ( $2^{\text {nd }}$ ed.). New York/London: Norton, 1981/1996.

10. Nelkin D., Lindee S. o.c., p. 149-150.

11. http://www.gutenberg.org/cache/epub/5322/pg5322.html

12. Aristoteles. Poetics. (The Loeb classical library 23). Cambridge: Harvard University Press / London: Heinemann, 1982.

13. Foucault (1975), p. 195.

14. Mill J. Le laboratoire Woyzeck : autopsie de trois mises à l'épreuve scéniques, 2008. http://www.archipel.uqam.ca/1745/1/M10620. pdf.

15. Zwart H. Understanding nature. Case studies in comparative epistemology. Dordrecht: Springer, 2008, p. 197 ff.

16. Wolf G. Georg Büchner's Woyzeck. A tragic example of human experimentation without informed consent. Pharos Alpha Omega Alpha Honor Medical Society; 67 (2): 23-8

17. http://gutenberg.spiegel.de/buch/6788/7.

18. Quincey, T. de. On Murder Considered as One of the Fine Arts, 1827. http://supervert.com/elibrary/thomas_de_quincey/.

19. http://www.europeana.eu/portal/record/08547/793D4CA5D3D699583185D5748C87C8E61A3EA18F.html

20. Lombroso C. L'uomo delinquente / Criminal man. Durham: Duke University Press, 1876/2006.

21. http://www.gutenberg.org/files/29895/29895-h/29895-h.htm, p. 255

22. Gould S.J. The mismeasure of man (2 ${ }^{\text {nd }}$ ed.). New York/London: Norton, 1981/1996.

23. Stoker B. Dracula. Hertfordshire: Wordsworth, 1897/1993.

24. Fukuyama F. Our posthuman future. Consequences of the biotechnology revolution. New York: Farrar, Straus and Giroux, 2002, p. 31.

25. Cf. Wrangham R., Peterson D. Demonic males: Apes and the Origins of Human Violence. Boston: Houghton Mifflin, 1997.

26. Aharoni Vincent G, Harenski C. Calhoun V. Sinnot-Armstrong W. Gazzaniga M. Kiehl K. Neuroprediction of future rearrest. 2013; PNAS 110: 6223-6228.

27. Cheema A., Virk A. Reinventing Lombroso in the Era of Genetic Revolution. International Journal of Criminology and Sociological Theory. 2012; 5 (2): 936-946.

28. Rothenberg K., Bush L. Manipulating fate: medical innovations, ethical implications, theatrical illuminations. Houston Journal of Health Law \& Policy. 12; 2012: 1-77.

29. Crichton M. Next. New York: Harper Collins, 2006.

30. Idem, p. 258. 